I Federal University of Rio de Janeiro (UFRJ), Department

of Political Science, Rio de Janeiro, RJ, Brazil

jaironicolau@gmail.com

II PhD in Political Science, State University of Rio de Janeiro, Institute of

Social and Political Studies (Iesp/Uerj), Rio de Janeiro, RJ, Brazil

lilianpcoliveira@gmail.com

\title{
POLITICAL SCIENCE IN BRAZIL: AN ANALYSIS OF ACADEMIC ARTICLES $(1966-2015)^{1}$
}

By coincidence, 2016 was the fiftieth anniversary of both the creation of UFMG's Department of Political Science and the launch of the journal Dados, which would become the main channel for disseminating a portion of the most important social science research conducted in the country. The two events prompted a series of commemorations and reviews, the most important being publication of the book A ciência política no Brasil (I960-20I5) (Avritzer, Milani \& Braga, 20I6), edited by the Brazilian Association of Political Science (ABCP), in which diverse authors analyse different aspects of the discipline's evolution in Brazil. ${ }^{2}$

The objective of this article is to analyse the content of the research undertaken by Brazilian political scientists over these five decades. The idea is to evaluate the discipline's production through the content of its periodicals: the four most traditional social science journals (Dados, Revista Brasileira de Ciências Sociais, Lua Nova and Novos Estudos Cebrap) and two periodicals focusing more directly on political science (Opinião Pública and Brazilian Political Science Review).

The text seeks to answer two questions. Which themes have political scientists been privileging in their research? And which methods have been employed to collect and process data in these studies? The fact that we are working with five decades of academic production allows us to observe any changes to the themes and methods privileged over time. ${ }^{3}$ 
Compared to other studies that make use of periodicals, this article is distinguished by two aspects. The first is that, since it mattered for us to know what Brazilian political scientists have written, we needed to establish a criterion to select just those authors connected to the discipline, excluding authors who published in the periodicals but are linked to other disciplines and/or those who are foreign. The second aspect concerns the scope. Unlike other works which have analysed a specific period, we have analysed all the articles published in six periodicals from their first issues until 2015.

\section{SELECTION OF AUTHORS AND PERIODICALS}

Periodicals are currently the main vehicle for the dissemination of scientific research. Consequently it is natural for them to be chosen as a privileged source for evaluating the development of the themes and methods used by researchers from a particular discipline. In the specific case of political science, there exist diverse examples of reviews based on the analysis of articles published in periodicals. Riba (I996) utilized 24 journals from different countries as a source for observing what type of mathematics the political scientists use in their research. Munck and Snyder (2007) have analysed the content and methods of the articles published in three comparative politics periodicals. Pierson (2007) selected three of the main political science periodicals in order to examine the utilization of qualitative methods in studies of American politics.

Recently, periodicals have also begun to be used to evaluate diverse aspects of the evolution of the social sciences and, in particular, Brazilian political science. Among the most wide-ranging reviews, we can highlight two doctoral theses that took diverse periodicals as their source (Leite, 2015; Oliveira, 2016) as well as the articles written by two leaders who participated actively in the institutionalization of the discipline in Brazil and who consulted the journal Dados exclusively as their source (Avritzer, 2016; Marenco, 2016). Other authors have made use of academic reviews to observe the production in specific areas of the discipline, such as comparative politics (Amorim Neto, 2010), normative political theory (Feres Junior, Campos \& Assumpção, 20I6), institutions (Limongi, Almeida \& Freitas, 20I6) and quantitative methods (Neiva, 20I5).

The studies based on periodicals published in the United States and in Europe set out from a simple premise, which is the existence of journals specialized in political science. Nobody is in any doubt that the articles published in the American Political Science Review or in the European Political Science Review were written by political scientists and constitute a good sample of the research undertaken. By contrast, in Brazil, until recently, there was no journal dedicated exclusively to political science - the first, the Brazilian Political Science Review, began to be published in 2007 . For a long period, the only option for a political scientist who wished to publish in the country were the broader social science journals, which group together works by sociologists, anthropologists and other researchers from humanities disciplines. 
How to separate from the thousands of articles published in the periodicals those written by political scientists? One possible solution is to select works not by the author's training or affiliation, but by the article's theme. An example is the aforementioned survey on normative political theory, which investigated the articles exploring the subject across a large number of journals (Feres Junior, Campos \& Assumpção, 2016); in this case, we have a survey of the volume of articles on a theme, but without distinguishing those written solely by political scientists. Another possibility is to identify the articles written specifically by political scientists. This was the option of the surveys produced by Leite (2015) and Oliveira (2016).

As the objective of our survey is to track the evolution of political science in the country, we opted to select just those articles written by political scientists or by them in partnership with researchers from other areas. In order to be included, the article authors had to meet one of the following requisites: define themselves as political scientists; participate in a department of political science; obtained a university degree (undergraduate, master and/or doctorate) in political science. We had little problem classifying the authors of recent articles, since practically all of them have a curriculum vitae available on CNPq's Lattes Platform. For the authors who published prior to the midI980s, though, the difficulties were greater, since during this phase of the discipline's institutionalization many authors who addressed strictly political themes still presented themselves as representatives of their discipline of origin (especially sociology, history, economics and law).

A second important decision for our survey was for authors to be considered to belong to Brazilian political science, since the periodicals also publish articles by foreign authors. We defined the following criteria for inclusion of an article, according to the profile of its author: Brazilians affiliated to research or teaching institutions in Brazil or abroad; foreign academics who teach and/or conduct research in Brazilian institutions. The majority of the articles selected are by Brazilians who work in Brazil, with a lower frequency written by Brazilians living abroad or foreigners teaching or conducting research in the country's institutions.

Today scientific journals have a similar pattern of organization, with a clear division established between articles, reviews and research notes. In the past, however, they assumed more diverse formats, with the occasional publication of interviews, opinion articles, lecture transcriptions and obituaries. In our survey we consider just those articles with a more traditional academic format, that is, with a minimum size, the presence of a bibliography and a systematic discussion of a particular theme.

Which Brazilian periodicals have been favoured by political scientists to divulge their research since the I96os? This is a very difficult question to answer, and even the most objective criteria (only the periodicals classified under CAPES's Qualis Periódicos system above BI level, for example) are ques- 
tionable when we analyse the literature over the long-term, since journals considered relevant today may have been marginal in the past.

The first step was to select the four most relevant journals from the community of Brazilian social sciences: Dados, Revista Brasileira de Ciências Sociais (RBCS), Novos Estudos Cebrap and Lua Nova. To these we added two more that have transformed into important publication channels for the discipline over the last decade: the Brazilian Political Science Review (the periodical of the Brazilian Political Science Association) and Opinião Pública, a journal that has recently published a large number of articles by political scientists. ${ }^{4}$ We believe that the articles appearing in these six journals are representative of the production of Brazilian political science. The only important exception relates to the area of international relations, which is under-represented, since it possesses its own periodicals not analysed by the survey. ${ }^{5}$

Between I966 and 2015, Brazilian political scientists published I,I96 articles in the six selected journals. Graph I (page 375) presents the total published articles, divided into ten five-year periods. What most stands out in the graph is the growth in the total number of work published, particularly over the last I5 years. To give an idea of the volume of this growth, over the last five years more articles have been published (325) than the total number published over the first three decades (I966-I995), which comes to just 250.

Graph 2 (page 376) shows the total number of articles published per five-year period, indicating the contribution of each periodical. Attention is drawn to the importance of the journal Dados in the first two decades. Created in 1966 at Candido Mendes University (RJ), following the foundation of the Rio de Janeiro Research Institute (IUPERJ) in I969, Dados began to be edited by researchers from this institution. For I5 years - until the emergence of Novos Estudos Cebrap, in I98I - it was practically the only periodical available for publication of research by social scientists in Brazil.

The number of articles published during the first two decades of academic political science in Brazil was very low (I04), representing an average of just five articles per year. These figures, nonetheless, more so than those from the following phases, may underestimate the discipline's vitality. The reason is that during this period books (individual or edited collections) were considered the main form of divulging the research made by social scientists. It is not difficult to list various works that were transformed into works fundamental to the discipline published during this period (Carvalho, I979; Lamounier \& Cardoso, I978; Lima Jr., I983; Reis, I978; Santos, I987; Soares, I973; Souza 1976). In addition, the periodicals still lacked the more professional traits that they acquired later, including regular publication of issues, anonymous reviewers and previously unpublished articles. 


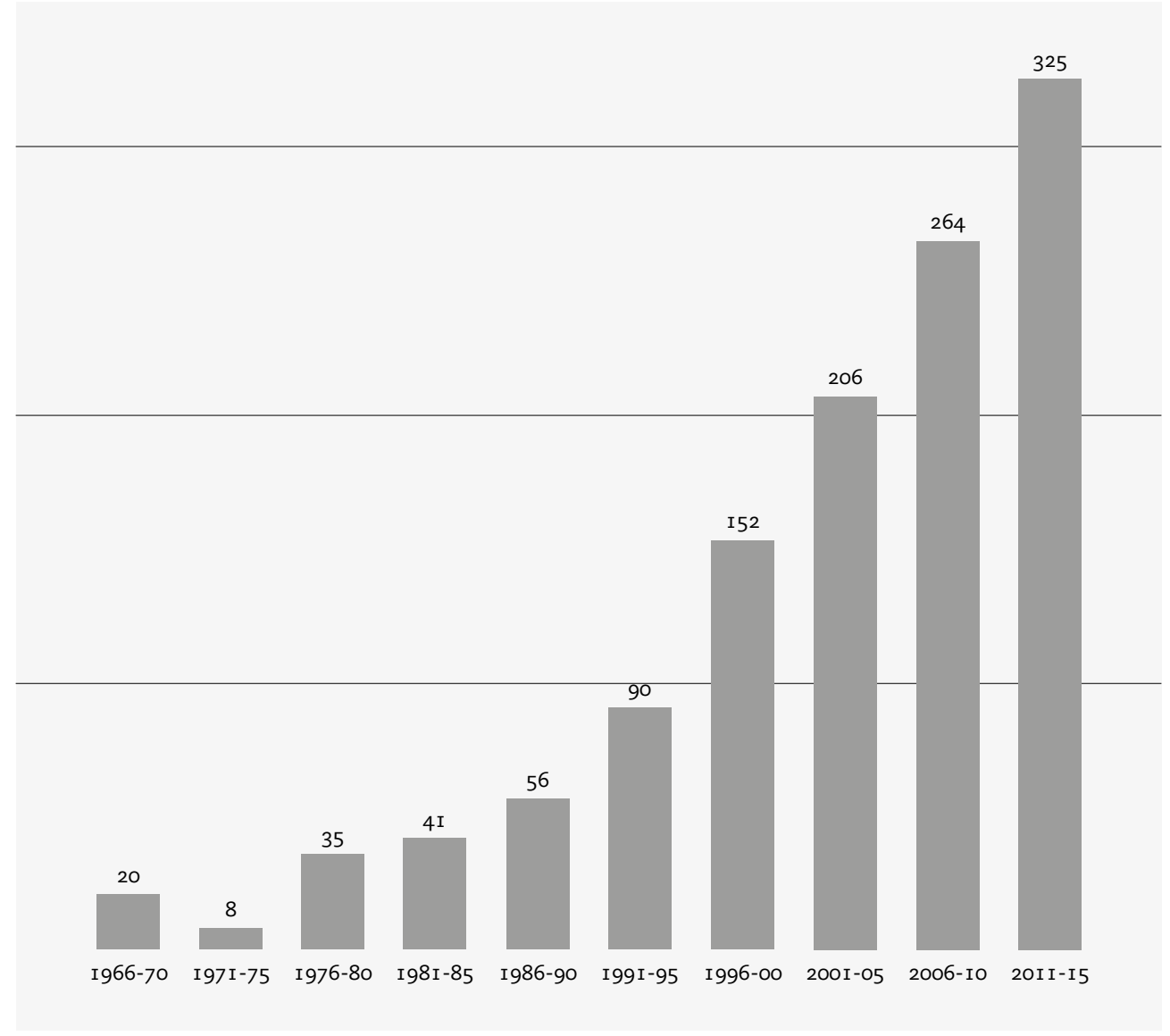

Graph I:

Total Brazilian political science articles published per five-year period (1966-2015)

Source:

Data collected in the journals BPSR, Dados,

Lua Nova, Novos Estudos, RBCS and Opinião Pública. 


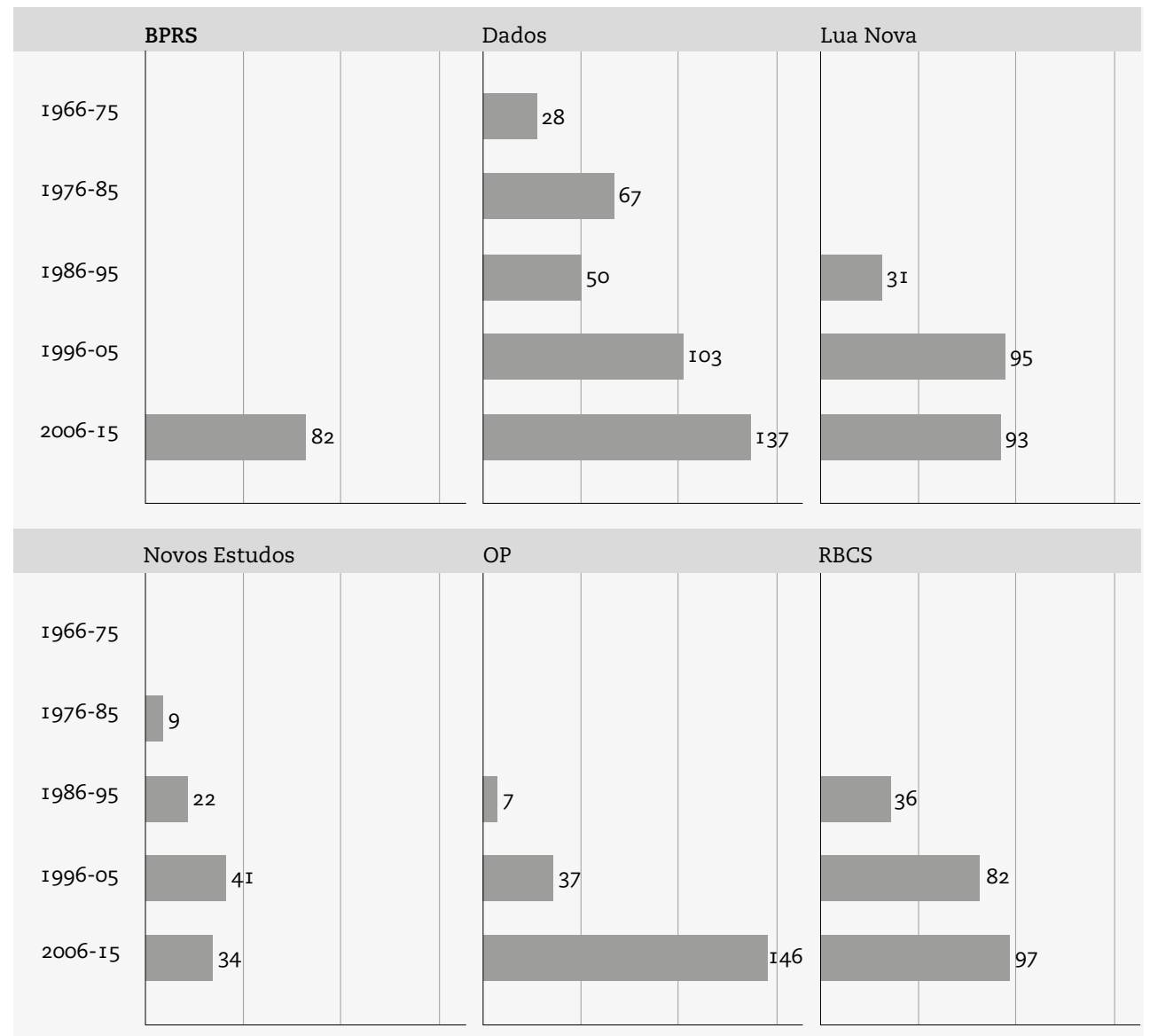

\section{Graph 2:}

Total number of Brazilian political science articles published per decade, according to periodical (I966-20I5)

Source:

Data collected in the journals BPSR, Dados, Lua Nova, Novos Estudos, RBCS and Opinião Pública. 
Another two new social science periodicals were launched in the second half of the I980s. Revista Brasileira de Ciências Sociais (RBCS), published by ANPOCS, began to circulate in I986. Lua Nova, a journal produced by the Contemporary Culture Studies Centre (CEDED), had been circulating since I984, but with the publication basically of short opinion articles; from I988, it changed and adopted a more academic format. In the second half of the I980s, the market for the publication of articles by political scientists would broaden with the consolidation of the four main journals from the area.

Opinião Pública was launched in I992. Unlike its predecessors, it was targeted at specific areas of the social sciences: political behaviour, political communication and public opinion. In its first years of existence, the journal was published at irregular intervals and included few articles by Brazilian political scientists. From the following decade, however, it started to turn into a journal dedicated primarily to political science, publishing works especially on electoral behaviour, parties and elections.

It is worth observing that the number of articles by political scientists published in the six journals increased substantially from the mid-I9gos onward (see Graph 2). We are unable to determine whether this phenomenon derives from a growth in the quantity of articles published by political scientists in detriment to authors from other areas, or whether it is the outcome of an increase in supply (the journals start to publish more issues per year). The fact is that we can say that by the start of the 2ooos, the country had a reasonable number of periodicals capable of providing an outlet for the most significant research being conducted by Brazilian political scientists. Notably too this period was marked by a change in the status of periodical articles, which began to be the most valorised form - particularly among academics who obtained their PhDs during the I990s - for disseminating political sciences studies in Brazil.

The journal of the ABCP, the Brazilian Political Science Review (BPSR), emerged in 2007 and is one of the landmarks in the discipline's institutionalization in the country. The new periodical began to be the natural outlet for Brazilian political scientists: in eight years, 82 articles were published. At this time, the cycle of valorisation of the periodicals would be completed as an outcome of three processes. The first was the classification of scientific periodicals by CAPES. The second was the utilization of the CAPES classification by postgraduate programs and by CNPq as a basis for evaluating researchers. Finally, the journals were forced to become more professional to meet the requirements for inclusion in the Scientific Electronic Library Online (SciELO) database.

In Graph 2 we can observe that the volume of articles in political science published over the last decade by the four main social science journals (Dados, RBCS, Lua Nova and Novos Estudos) has not altered significantly. This intense growth is associated with two factors: the advent of the BPSR and the high number of articles in Opinião Pública, which, with 146 articles published, became the main disseminator of research by Brazilian political science between 2006 and 2015. 


\section{THEMATIC AREAS}

What themes do political scientists address in their research? Have there been any significant changes to the research agenda of the political science community over these five decades? To answer these questions, we classify the articles according to their main theme - the complete list of the themes of the articles is presented in Appendix I. These themes have been grouped into eight major areas: political theory and thought; political behaviour; representative institutions; public policies; non-representative institutions; international relations; systems of government and institutional frameworks; civil society actors. The articles that discuss themes appearing with less frequency were combined into a ninth category: other.

Graph 3 (page 379) shows the percentage of articles in these nine thematic areas. The area of political theory and thought appears in first place with 2I\% of the total - the area of Brazilian political thought contributed just $4 \%$ of the total number of articles analysed; in it we included articles from different intellectual styles and traditions, which concentrate on specific authors, conceptual discussions and schools of thought. ${ }^{6}$ We noted an important change in this area over time. Until the I980s, studies focused primarily on classic thinkers of political history. From the I99os, discussions of normative political theory began to predominate (Feres Junior, Campos \& Assumpção, 2016). It is worth emphasizing the role of the journal Lua Nova as a priority channel for publishing works from this area, in particular normative political theory. To a certain extent, the predominance of texts on political theory reflects the dominance of the courses in this area offered in Brazilian postgraduate education. ${ }^{7}$ A survey of the courses offered at the University of São Paulo (USP) and at the University Research Institute of Rio de Janeiro (IUPERJ) - two of the country's most important programs - between I97I and 20II, for example, showed that political theory courses appear in first place and represent $30 \%$ of the courses offered (Oliveira \& Nicolau, 2012).

The area of political behaviour appears in second place with a total of I5\% of all articles published. The tradition of electoral studies in Brazil precedes the creation of the first political science programs. Since 1956, the Revista Brasileira de Ciência Política, edited by Orlando de Carvalho, was responsible for publishing a large number of works on the theme (Lamounier \& Kinzo, I978). In the I970s, the research studies conducted by a consortium of institutions on the electoral behaviour of residents from various cities were fundamental to consolidating the use of surveys in Brazilian political science (Lamounier \& Cardoso, I978; Reis, I978). From 2002, the Brazilian Electoral Study (ESEB), with its opinion surveys conducted at national level, would become the main source for researchers dedicated to the study of elections in Brazil. 


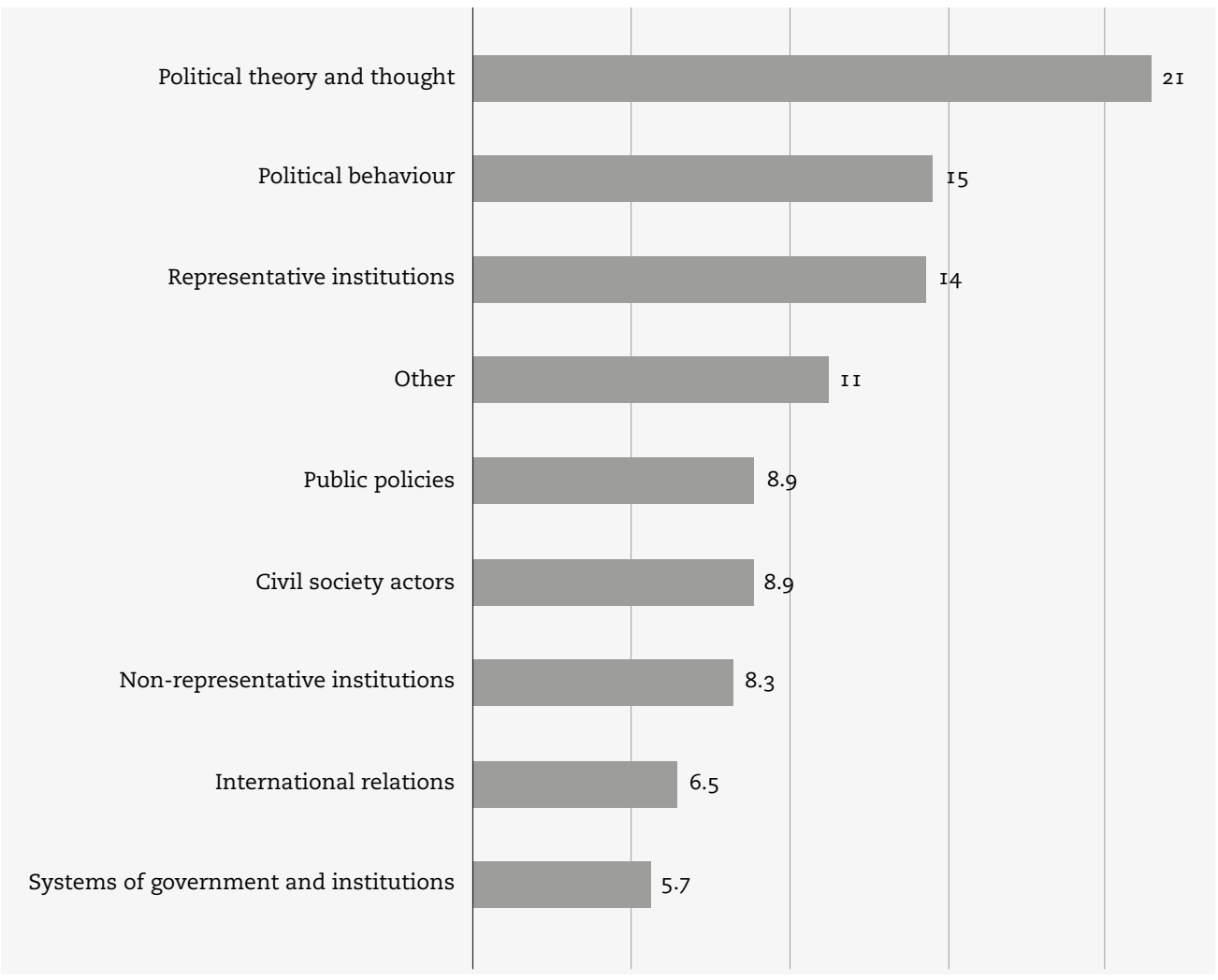

Graph 3:

Percentage of Brazilian political science articles published according to thematic area (1966-2015)

Source:

Data collected in the journals BPSR, Dados, Lua Nova, Novos Estudos, RBCS and Opinião Pública. 
Graph 4 (page 38I)presents the total number of articles from each area by decade. Attention is drawn to the growth in articles on political behaviour over the last decade. This growth is associated with the role that the journal Opinião Pública came to play in the discipline as the main diffusor of research on electoral behaviour and citizen attitudes and values.

The area of representative institutions was responsible for $14 \%$ of the articles published between I966 and 2015. Here we combine articles that discuss different dimensions of political representation (parties, party systems, Congress, relations between Executive and Legislature, electoral systems and the profile of the parliamentary elite). Unlike the articles that explicitly analyse the behaviour of citizens, whether during the electoral period or outside it, the articles on representative institutions privilege the behaviour of the representatives, the organisation that connects the electors to the world of representatives (parties) and the rules that regulate the process of choosing the representatives (electoral systems). During the period, the number of works on this theme grew significantly (see Graph 4); this growth is strongly associated with the wave of studies on the National Congress (particularly the Chamber of Deputies) and the functioning of the Brazilian presidential system (Figueiredo \& Santos, 20I6; Limongi, Almeida \& Freitas, 2016).

The articles on public policies account for $9 \%$ of the articles published during the period. This area encompasses texts on social policy (education, health, pensions and social welfare), economic policy and other State policies (security, science and technology, and defence). One datum that stands out in Graph 4 is that the growth in the public policies area was relatively less intense compared to the three areas observed previously. This fact is somewhat surprising, especially given the centrality of the debate on public policies in the country over recent decades. This may have to do with the nature of the area itself, probably less specifically characterized as political science. One hypothesis is that much of the research in the public policy area has been captured by other areas - for example, educators specialized in educational policy, or sanitarians researching health policies.

The expansion of postgraduate courses in political science in Brazil over the last decade is largely due to the creation of international relations programs (Marenco, 2016). Yet the strength of this area is not reflected in the production of the six journals analysed here: just $7 \%$ of articles published in the period concern international relations. This figure should be treated with care, however, since the area has specialized journals - Contexto Internacional and Revista Brasileira de Relações Internacionais, for example that were not included in the present survey, which contributes to underestimating the global production of political scientists specialized in international policy.

The five areas analysed (political theory, political behaviour, representative institutions, public policies and international relations) form the 


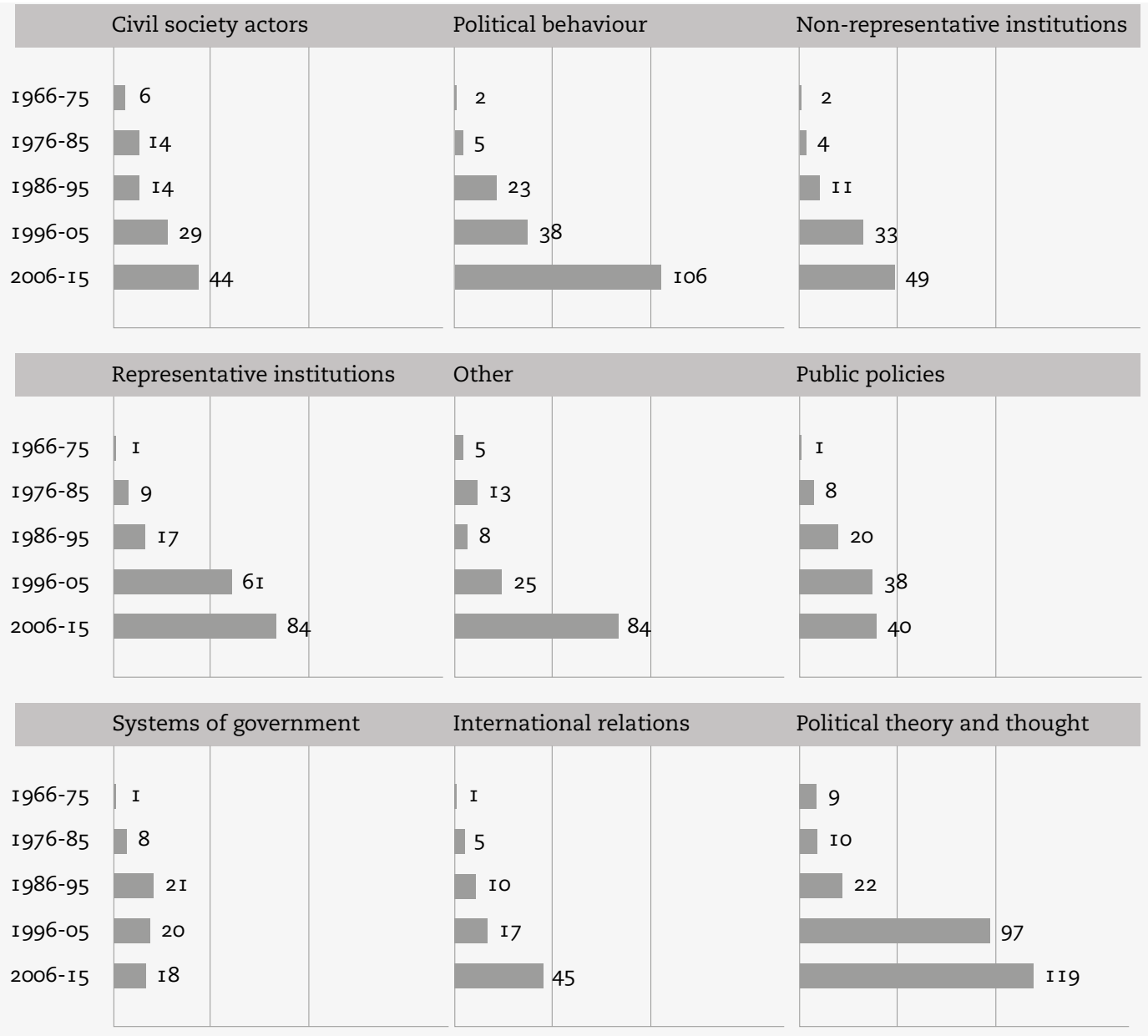

Graph 4:

Total number of Brazilian political science articles published per decade, according to thematic area Source:

Data collected in the journals BPSR, Dados, Lua Nova, Novos Estudos, RBCS and Opinião Pública. 
core of the evolution of political science in Brazil. ABCP's most long-running workgroups and those organized by political scientists at ANPOCS reflect, with small variations, these five areas. The 'other' category shown in Graphs 3 and 4 combines various topics that are not so clearly institutionalized.

The area defined as non-representative institutions covers articles on the following topics: State structures (bureaucracy, regulatory agencies, public administration); federalism, municipalism and decentralization; the Judiciary; profile of the bureaucratic elite. The more general studies on political systems, institutional frameworks in democracies, and the transition to democratic systems were group under the label of systems of government. The area generically referred to as civil society actors consists of monographs on particular civil society groups: business sectors, the media (excluding studies of electoral campaigns and party election broadcasts), military forces, social movements and unions. Together the articles from these three areas account for $23 \%$ of the total (see Graph 3 ).

\section{METHODS}

In an important article evaluating the state of political science in Brazil in the mid-2000s, Soares (2005: I) identified what he described as the discipline's "methodological Achilles' heel." His concerns are encapsulated in the first two sentences of his text: "Political science in Brazil is facing a difficult period in which professional production and research is running against the tide of history. A certain hostility exists in relation to quantitative methods and statistics. However, its place has not been taken up by rigorous qualitative methods, but rather by an absence of methods and rigour." His diagnosis is based on comparison with the situation observed in other countries. Studies of the development of political science in the United States and in some European countries, for example, show that statistics exerted an increasingly powerful influence on the discipline over the last three decades (Bennett, 2003; Pierson, 2007; Riba, 1996). For Soares (2005), the fact that Brazilian postgraduate programs have neglected methodological training is one of the main reasons for the discipline lagging behind compared to other countries.

Methodology, one of the most polysemic terms in the social sciences, recurrently appears in two ways. The first is associated with discussions more closely in tune with the philosophy of science and epistemology; the discussion on causality in the social sciences illustrates one of the fundamental concerns of those employing the term in this acceptation (Brady, 2008). The second associates the term with research methods, especially with specific forms of gathering and processing data, whether through numerical or non-numerical procedures (Moses, Rihoux \& Kittel, 2005).

Soares (2005) uses the term methodology in this second sense. What Brazilian political science is missing, he argues, is more elaborate training 
in data processing (whether qualitative or quantitative). In the present text, we prefer to use the term method to speak specifically of data collection and processing procedures.

Since the publication of the survey by Soares (2005), postgraduate courses in political science - among which we can highlight those run at USP, UFMG and UFPE - have evidently begun to pay greater attention to the discussion of methods. A good example of this movement is the summer course offered since 2010 by the International Political Science Association (IPSA), in association with USP's Department of Political Science. The course has become an ideal environment for exposing students to recent methodological debates and to training in specific research methods.

We were especially interested in evaluating the utilization of quantitative methods in the published articles. The diverse quantitative procedures were divided into four groups: basic descriptive statistics (percentage tables and frequency); advanced descriptive statistics (indices, scales, means and correlations); multivariate analysis (network analysis, factor analysis, cluster analysis, multidimensional scale and correspondence analysis); regression techniques (linear, non-linear/loglinear, logistics, probit and time series). Table I shows the percentage of articles that used some of these techniques over the period. ${ }^{8}$

Brazilian political scientists have always made use of descriptive statistics in their texts. We were able to observe that even in the first issues of the journal Dados, some authors had produced simple tables to present the results of their research. Over the last decade, half of the articles published employed some kind of basic statistics to summarize data. It should be stressed, however, that these high figures do not necessarily reflect a process of 'quantification' of Brazilian political science, given that, in many cases, such data is used in isolated form as a table, a graph, for instance in primarily qualitative works.

The application of more advanced descriptive statistical techniques particularly indices and correlations - has increased constantly over the period, rising to $22 \%$ in the last ten years. On the other hand, the use of multivariate techniques is fairly limited: employed in just $3 \%$ of the articles.

What most calls attention in Table I (page 384) is the increase in the frequency of regression techniques. The first text to use regression analysis was published in the journal Dados, in I990. Since then growth has been continuous. In the first decade, $19 \%$ of articles presented some model of regression analysis. Two journals have been favoured for the publication of articles utilizing this technique: $30 \%$ of what was published in Opinião Pública made use of regression analysis, as well as $26 \%$ of the articles appearing on the pages of BPSR. The volume published in the other journals is as follows: Dados (II\%), RBCS (7\%), Novos Estudos Cebrap (5\%) and Lua Nova (2\%). 


\begin{tabular}{l|l|l|l|l|l|l}
\hline & I966-75 & I976-85 & I986-95 & I996-05 & 2006-I5 & Total \\
\hline Basic statistics & 32 & 29 & 32 & 44 & 49 & 44 \\
\hline Advanced statistics & I I & 8 & I 2 & I7 & 22 & I8 \\
\hline Multivariate techniques & - & - & 2 & 4 & 5 & 4 \\
\hline Regression analysis & - & - & 3 & 8 & I9 & I2 \\
\hline
\end{tabular}

Table I:

Percentage of Brazilian political science articles making use of quantitative methods (I966-2015)

Source:

Data collected in the journals BPSR, Dados, Lua Nova,

Novos Estudos, RBCS and Opinião Pública.

The recent employment of regression techniques by Brazilian political science has followed a similar process to those in other countries, particularly to political science in the United States, peaking in the I990s and 2000s. A survey conducted in the mid-I9gos shows that regression analysis was present in I $9 \%$ of articles, rising to $54 \%$ in the principal American periodical - American Political Science Review - and 33\% in the principal British periodical - British Journal of Political Science (Riba, I996, p. 491, 504). ${ }^{9}$

More than just the employment of a new statistical technique, the use of regression is associated with a new model of article that became increasingly prominent in the journals, especially from the second half of the I99os. With some variations, this model has more or less the following characteristics: use of an original database; presentation of the pertinent literature, with respect both to the research question and to the variables that are used; measurement, via regression, of the impact of the independent variables on a dependent variable.

The range of articles that make no use of quantitative methods is considerable - theoretical texts on concepts and the history of thought; descriptive studies of institutions; case studies of organizations; studies of the profile of political leaders - and the attempt to map them is not a present objective of our research. What we have done is identify the extent to which three techniques from the 'family' of qualitative methods (participant observation and interviews; focal groups; oral history) were employed by political scientists. To our surprise, the use of focal groups and oral history is extremely limited; just two articles made use of them. Meanwhile participant observation and interviews are present in 49 texts ( $5 \%$ of the total). 
This small number of articles using qualitative methods is more than likely the outcome of a lack of training among students. Few departments offer regular courses in qualitative research, a trend probably aggravated by the boom in statistics courses from the mid-200os. In the division of knowledge of the Brazilian social sciences, the qualitative techniques ended up becoming an area dominated by anthropology (par excellence) and sociology. Perhaps the diagnosis of a methodological lag of political science makes more sense today in relation to the studies conducted by political scientists without the use of statistics. This sensation is all the greater when we observe the advances made by international political science in the area of qualitative research over the last decade (Goertz \& Mahoney, 20I2; Schneider\& Wagemann 20I2).

\section{FINAL CONSIDERATIONS}

Some aspects should be highlighted in our effort to map the output of political science published in Brazilian periodicals. The first of them is the strong increase in the number of articles published, particularly over the last decade. To a large extent this growth reflects the discipline's expansion in Brazil. From an incipient community formed by alumni of other areas in the I96os, political science expanded and today has hundreds of professionals working in dozens of teaching and research units. Beyond this direct effect of academic expansion, the high number of articles is also a product of the country's scientific policies, which began to confer greater weight to periodicals, reducing the importance of books. In the past, publishing articles was just one of the options available to a professional from the area. For a political scientist to advance in an academic career today, it is virtually obligatory to publish in academic periodicals.

A second aspect worth emphasizing is the diversity of production. Today Brazilian political science is a discipline characterized by a broad dispersion of research topics. Despite this dispersion, three thematic areas contributed more strongly to the growth in the number of published articles: political theory and thought; political behaviour and representative institutions. The texts that appear in the journals in these three areas correspond to $51 \%$ of all those published in five decades.

One last aspect to be highlighted concerns the methods favoured by political scientists in their studies. Contrary to a cliché that took root in some intellectual circles, Brazilian political science is far from being a quantitative discipline. Over the last decade, half of the articles made use of statistics, but in most cases merely as a simple summarization in table or graph form. The discipline's quantification explicitly appears in the use of regression analysis, particularly in studies of elections, political behaviour and the Legislature. 
Although the articles making no use of statistics represent the other half of those published, the use of qualitative methods is still timid in Brazil. Today Brazilian political science's biggest shortfall is in the area of qualitative research. The qualitative revolution that has shaped much of international political science has yet to arrive here. Discussions on a more systematic use of history (historic institutionalism, comparative historical method and process-tracing) and on the use of logic (qualitative comparative analysis and fuzzy set analysis) have yet to influence the research carried out in the country. For this reason, a decade after the diagnosis made by (2005), it is perhaps more accurate to say that Brazilian political science's Achilles's heel is its qualitative methodology.

Received on 2I/og/20I6 | Revised on 24/oI/20I7 | Approved on I4/02/2017

Jairo Nicolau is Full Professor of the Department of Political Science at UFRJ and a CNPq researcher. Author of Representantes de quem? Os(des)caminhos do seu voto da urna à Câmara dos Deputados (2017).

Lilian Oliveira has a PhD in Political Science from IESP/ UERJ, where she presented the thesis A trajetória da ciência política brasileira: uma análise da produção e da formação acadêmica (I966-2014), in 2016. 


\begin{tabular}{|c|c|c|}
\hline Area & Theme & $\begin{array}{l}\text { Number } \\
\text { of articles }\end{array}$ \\
\hline \multirow{3}{*}{$\begin{array}{l}\text { Political theory and } \\
\text { thought }\end{array}$} & Political theory & 215 \\
\hline & Brazilian political theory & 42 \\
\hline & Total & 257 \\
\hline \multirow{3}{*}{ Political behaviour } & Elections, campaigns and electoral behaviour & II6 \\
\hline & Citizen attitudes, values and trust & 58 \\
\hline & Total & I74 \\
\hline \multirow{3}{*}{$\begin{array}{l}\text { Representative } \\
\text { institutions }\end{array}$} & $\begin{array}{l}\text { Legislature, parliamentary career and } \\
\text { presidential system }\end{array}$ & 97 \\
\hline & Political parties, party system and electoral systems & 75 \\
\hline & Total & 172 \\
\hline \multirow{4}{*}{ Public policies } & Social policy & 48 \\
\hline & Economic and development policy & 42 \\
\hline & $\begin{array}{l}\text { Other (scientific, urban, energy, security } \\
\text { and defence) }\end{array}$ & I7 \\
\hline & Total & 107 \\
\hline \multirow{6}{*}{ Civil society actors } & Social movements and associations & 32 \\
\hline & Media and politics & 27 \\
\hline & Unionism & 23 \\
\hline & Businesses & I6 \\
\hline & Military forces & 9 \\
\hline & Total & 107 \\
\hline \multirow{5}{*}{$\begin{array}{l}\text { Non-representative } \\
\text { institutions }\end{array}$} & Federalism and decentralization & 34 \\
\hline & Political and bureaucratic elite & 23 \\
\hline & Judiciary & 22 \\
\hline & $\begin{array}{l}\text { Bureaucracy, regulatory agencies and } \\
\text { administrative reform }\end{array}$ & 20 \\
\hline & Total & 99 \\
\hline \multirow[t]{2}{*}{ International relations } & $\begin{array}{l}\text { Foreign policy and international relations, } \\
\text { international organizations }\end{array}$ & 78 \\
\hline & Total & 78 \\
\hline \multirow[t]{2}{*}{ International relations } & $\begin{array}{l}\text { Systems of government and institutional } \\
\text { frameworks }\end{array}$ & 68 \\
\hline & Total & 68 \\
\hline \multirow{6}{*}{ Other } & Social structure and inequality & 42 \\
\hline & Other & 35 \\
\hline & $\begin{array}{l}\text { Political participation, councils and } \\
\text { participatory budget }\end{array}$ & 35 \\
\hline & Methods & I4 \\
\hline & Formation and history of academic disciplines & 9 \\
\hline & Total & I35 \\
\hline
\end{tabular}

Appendix:

Number of political science articles published in periodicals, according to area and theme (1966-2015)

Source:

Data collected in the journals BPSR, Dados, Lua Nova, Novos Estudos, RBCS and Opinião Pública. 


\section{NOTES}

I This article is a result of the research project 'The production of political science in Brazil,' financed by CNPq (201220I5). We would like to thank the journal reviewers for their excellent comments.

2 For general assessments of the development of political science in Brazil, see Almeida, 2005; Amorim Neto \& Santos, 2015; Lamounier, I982; and Lessa, $201 \mathrm{I}$.

3 In seminars where we presented the preliminary results of the survey, we were asked why we had not analysed books published by political scientists. The analysis of books is important - especially up to the I9gos when a good portion of the production was published in edited collections - and a survey dedicated to them will serve to complement the analysis undertaken here. Even so, we were able to observe that, even in the era of collections, many of the studies made by political scientists were also published simultaneously in periodicals.

4 Over recent years two social science journals (Sociologia e Política, at UFPR, and Sociedade e Estado, at UnB) have transformed into important outlets for the publication of works by political scientists. The non-inclusion of these journals underestimates the quantity of articles published, but probably does not affect their thematic distribution. In a preliminary analysis we observed that the two journals publish a wide range of research themes and styles.

5 The exclusion of journals of international relations derives from the fact that the academics involved in this initial phase of the survey were not familiar with the theme. Our intention is to include these journals during a later phase of the survey, in partnership with specialists from the area.

6 For convenience here we follow the tradition of Brazilian political science of using the term 'theory' in association with classic authors from the history of political thought. Obviously this does not mean that the works grouped in the other areas are atheoretical.

7 The postgraduate programs in political science offered in Brazil traditionally constructed their courses around clas- 
sic thinkers (beginning with the Greeks or, alternatively, with Machiavelli). The model was adopted in undergraduate studies where the introductory courses practically repeat the canon. A student will necessarily be exposed to the classic authors of the discipline, but may be trained without knowing about some other important areas of the discipline. This model perhaps helps explain the high number of articles from the area of the theory and history of political thought in the academic production analysed here.

8 For the creation of these four groups, we drew inspiration from Riba (1996).

9 The widespread and sometimes inappropriate use of regression techniques has been the target of much criticism (Freedman, I99I; Kincaid, 2012).

\section{BIBLIOGRAPHY}

Almeida, Maria Hermínia Tavares de. (2005). Ciência política no Brasil: avanços e desafios. In: Martins, Carlos Benedito (ed.). Para onde vai a pós-graduação em ciências sociais no Brasil. Bauru: Edusc, p. I05-I2I.

Amorim Neto, Octavio. (2010). A política comparada no Brasil: a política dos outros. In Lessa, Renato (ed.). Horizontes das ciências sociais: ciência política. São Paulo: Anpocs, p. 32I-340.

Amorim Neto, Octavio \& Santos, Fabiano. (20I5). La ciencia política en Brasil en la última dácada: la nacionalizatión y lenta superación del parroquialismo. Revista de Ciencia Política, 35/I, p. I9-3I.

Avritzer, Leonardo. (2016). O papel do pluralismo na formação da ciência política no Brasil. In: Avritzer, Leonardo; Milani, Carlos R.S. \& Braga, Maria do Socorro Sousa (eds.). A ciência política no Brasil (I960-20I5). Rio de Janeiro: Ed. FGV, p. I5I-I63.

Avritzer, Leonardo; Milani, Carlos R.S. \& Braga, Maria do Socorro Sousa (eds.). (20I6). A ciência política no Brasil (I96020I5). Rio de Janeiro: Ed. FGV.

Bennett, Andrew. (2003). Do we preach what we practice? A survey of methods in political science journals and cur- 
ricula. Political Science and Politics, p. 373-378. Available at: $<$ http://www.uvm.edu/ dguber/POLS293/articles/bennett. pdf $>$. Accessed I4/08/20I7.

Brady, Henry E. (2008). Causation an explanation in social science. In: Collier, David; Brady, Henry E. \& Box-Steffensmeier, Janet (eds.). The Oxford Handbook of Political Methodology. Oxford: Oxford University Press, p. 217-70.

Carvalho, José Murilo de. (I979). A construção da ordem: a elite política imperial. Rio de Janeiro: Campus.

Feres Junior, João; Campos, Luiz Augusto \& Assumpção, San Romanelli. (20I6). Teoria política normativa. In: Avritzer, Leonardo; Milani, Carlos R.S. \& Braga, Maria do Socorro Sousa (ed.). A ciência política no Brasil (I960-20I5). Rio de Janeiro: Ed. FGV, p. 195-240.

Figueiredo, Argelina Cheibub \& Santos, Fabiano. (2016). Estudos legislativos no Brasil. In: Avritzer, Leonardo; Milani, Carlos R.S. \& Braga, Maria do Socorro Sousa (eds.). A ciência política no Brasil (1960-20I5). Rio de Janeiro: Ed. FGV, p. I69-I94. Freedman, David A. (I99I). Statistical models and shoe leather. Sociological methodology, 2I, p. 29I-3I3.

Goertz, Gary \& Mahoney, James. (2012). A tale of two cultures: qualitative and quantitative research in the social sciences. Princeton: Princeton University Press.

Kincaid, Harold. (2012). Mechanisms, causal modeling and the limitations of traditional multiple regression. In: Kincaid, Harold (ed.). The Oxford Handbook of Philosophy of Social science. Oxford: Oxford University Press, p. 46-64.

Lamounier, Bolívar. (1982). A ciência política no Brasil: roteiro para um balanço crítico. In: Lamounier, Bolívar (ed.) A ciência política nos anos 80. Brasília: Editora UNB.

Lamounier, Bolívar \& Cardoso, Fernando Henrique. (I978). Os partidos e as eleições no Brasil. São Paulo: Paz e Terra.

Lamounier, Bolívar \& Kinzo, Maria D’Alva. (1978). Partidos políticos, representação e processo eleitoral no Brasil (I945-I978). BIB-Boletim Informativo e Bibliográfico de Ciências Sociais, 5, p. II-32.

Leite, Fernando. (20I5). O campo de produção da ciência política brasileira contemporânea. PhD Thesis. Departamento de Sociologia e Política/Universidade Federal do Paraná. 
Lessa, Renato. (20II). Da interpretação à ciência: por uma história filosófica do conhecimento político no Brasil. Lua Nova, 82, p. 17-60.

Lima Jr., Olavo Brasil de. (1983). Os partidos políticos brasileiros: a experiência federal e regional: I945-1964. Rio de Janeiro: Graal.

Limongi, Fernando; Almeida, Maria Hermínia Tavares de \& Freitas, Andrea. (2016). Da sociologia ao (neo)institucionalismo: 30 anos que mudaram a ciência política no Brasil. In: Avritzer, Leonardo; Milani, Carlos R.S. \& Braga, Maria do Socorro Sousa (eds.). A ciência política no Brasil (I960-20I5). Rio de Janeiro: Ed. FGV, p. 60-85.

Marenco, André. (20I6). Cinco décadas de ciência política no Brasil: institucionalização e pluralismo. In: Avritzer, Leonardo; Milani, Carlos R.S. \& Braga, Maria do Socorro Sousa (eds.). A ciência política no Brasil (I960-20I5). Rio de Janeiro: Ed. FGV, p. I32-I66.

Moses, Jonathon; Rihoux, Benoît \& Kittel, Bernhard. (2005). Mapping political methodology: reflections on a european perspective. European Political Science, 4/I, p. 55-68.

Munck, Gerardo L. \& Snyder, Richard. (2007). Debating the direction of comparative politics: an analysis of leading journals. Comparative Political Studies, 40/I, p. 5-3I.

Neiva, Pedro. (20I5). Revisitando o calcanhar de aquiles metodológico das ciências sociais no Brasil. Sociologia, Problemas e Práticas, 79, p. 65-83.

Oliveira, Lilian. (20I6). A trajetória da ciência política brasileira: uma análise da produção e da formação acadêmica (I96620I4). PhD Thesis. Instituto de Estudos Sociais e Político/ Universidade do Estado do Rio de Janeiro.

Oliveira, Lilian \& Nicolau, Jairo. (20I2). Métodos e metodologias da ciência política no Brasil: uma análise dos currículos de pós-graduação. Paper presented at the ABCP's $8^{\text {th }}$ meeting, on August $2^{\text {nd }}$, in Gramado, RS.

Pierson, Paul. (2007). The costs of marginalization: qualitative methods in the study of american politics. Comparative Political Studies, 40/2, p. I46-I69.

Reis, Fábio Wanderley. (I978). Os partidos e o regime. São Paulo: Símbolo. 
Riba, Clara. (I996). The use of mathematics in political science: a survey of European and American journals. European Journal of Political Research, 29/4, p. 477-508.

Santos, Wanderley Guilherme dos. (1987). Cidadania e justiça: a política social na ordem brasileira. $2^{\text {nd }}$ ed. Rio de Janeiro: Campus.

Schneider, Carsten Q. \& Wagemann, Claudius. (2012). Settheoretic methods for the social sciences: a guide to qualitative comparative analysis. Cambridge: Cambridge University Press.

Soares, Gláucio Ary Dillon. (2005). O calcanhar metodológico da ciência política no Brasil. Sociologia, Problemas e Práticas, 48, p. 27-52.

Soares, Gláucio Ary Dillon. (1973). Sociedade e política no Brasil. São Paulo: Difel.

Souza, Maria do Carmo Campello de. (1976). Estado e partidos políticos no Brasil. São Paulo: Editora Alfa-Omega. 
Palavras-chave

Ciência política no Brasil; métodos em ciência política; história da ciência política; periódicos de ciência política; produção da ciência política no Brasil.

\section{A CIÊNCIA POLÍTICA NO BRASIL: UMA ANÁliSE A PARTIR DOS ARTIGOS ACADÊMICOS (1966-2015)}

\section{Resumo}

O artigo analisa a produção da ciência política brasileira publicada em seis periódicos (Dados, Revista Brasileira de Ciências Sociais, Novos Estudos, Lua Nova, Opinião Pública e Brazilian Political Science Review) ao longo de cinco décadas (I966 e 20I5). O texto enfatiza dois aspectos. O primeiro é a distribuição da produção pelas grandes áreas temáticas da ciência política. O segundo é o tipo de método privilegiado, com ênfase na variedade de métodos estatísticos utilizados pelos autores. Se constata o crescimento do volume de artigos publicados pelos cientistas políticos brasileiros, particularmente a partir da segunda metade dos anos I990. Uma das conclusões do artigo é que, embora faça uso de estatística - e nos últimos anos técnicas mais avançadas tenham se difundido -, a ciência política brasileira está longe de ser considerada uma disciplina eminentemente quantitativa.

\section{POLITICAL SCIENCE IN BRAZIL:}

\section{AN ANALYSIS OF ACADEMIC ARTICLES}

\section{(1966-2015)}

\section{Keywords Abstract}

Political science in Brazil; methods in political science;

history of political science in Brazil; journals of political science; production of Brazilian political science. two aspects: first, the distribution of articles by thematic
The article analyses the production of Brazilian political science, as published in six periodicals (Dados, Revista Brasileira de Ciências Sociais, Novos Estudos Cebrap, Lua Nova, Opinião Pública and Brazilian Journal of Political Science) over a period of five decades (I966-2015). The text emphasizes areas of political science; and second, the type of method used, with an emphasis on the variety of statistical procedures used by the authors. The article observes the growing volume of articles published by Brazilian political scientists, particularly from the second half of the I99os. One of the conclusions of the paper is that although statistics are used - and in recent years more advanced techniques have spread - Brazilian political science is far from being considered an eminently quantitative discipline. 